\title{
Changes in plasma concentrations of thyroxine binding prealbumin and retinol binding protein in Japanese quail after hatching
}

\author{
BY D. J. HEAF, M. EL-SAYED* AND J. GLOVER \\ Department of Biochemistry, University of Liverpool, \\ P.O. Box I47, Liverpool, L69 $3 B X$ \\ (Received 3 December 1979 - Accepted 3 June 1980)
}

\begin{abstract}
I. Male and female Japanese quail (Coturnix coturnix japonica) were reared under short daily photoperiods ( $8 \mathrm{~h}$ light-16 $\mathrm{h}$ dark) to inhibit sexual development with free access to food and water. Blood was sampled at frequent intervals for 13 weeks from hatching in order to monitor the developmental changes in plasma concentrations of the two proteins which are important in the transport of retinol, retinol-binding protein (RBP) and thyroxine-binding prealbumin (TBPA).

2. Measurements of body-weight, blood packed cell volume and plasma total protein concentration showed that the birds had a normal pattern of growth and haematological development. Plasma concentrations of TBPA, total immunoreactive RBP (IRBP) and holoRBP were 220,60 and $45 \mu \mathrm{g} / \mathrm{ml}$ respectively in $\mathrm{I}-\mathrm{d}$-old quail and rose to 430,165 and $140 \mu \mathrm{g} / \mathrm{ml}$ at $14 \mathrm{~d}$ of age, which was $10 \mathrm{~d}$ after the corresponding change in total protein. Neither RBP nor TBPA concentrations were significantly different between the sexes during the 13 weeks, but there were minor fluctuations in concentration within relatively narrow limits.
\end{abstract}

A pronounced variation in the plasma concentration of retinol-binding holoprotein (holoRBP) during the breeding season of sheep was reported by Glover et al. (1976). Further work on the involvement of vitamin $A$ in animal reproduction has focused on the Japanese quail (Coturnix coturnix japonica). The quail, like sheep, has an annual breeding cycle and has been extensively studied with regard to its reproductive endocrinology; it is, however, more convenient than sheep for investigation under laboratory conditions. Plasma RBP in adult quail of both sexes shows a steep rise at the beginning of the breeding season, in spring, followed by a decline in late summer, when exposed to annual photoperiod cycles of artificial (Heaf \& Glover, 1979) or natural (Glover et al. 1980) lighting. These changes in retinol transport are thought to be important in maintaining adequate supplies of the vitamin to meet the requirements for growth and development of reproductive tissues.

Thyroxine-binding prealbumin (TBPA) is another protein involved in the transport of retinol. In higher vertebrate species it forms a complex with plasma RBP and probably reduces the rate of loss of the relatively small RBP molecule by ultrafiltration through the kidney (Kanai et al. 1968). In quail, TBPA concentration has also been shown to undergo a seasonal cycle which is in marked contrast to that of RBP. While RBP climbs steeply to a maximum in the spring, TBPA falls steadily, then remains low until the end of the summer when it begins a rise to its midwinter maximum level again (El-Sayed et al. 1980).

The relative changes in concentrations of these two proteins may be significant for retinol transport; there is a molar excess of RBP in the plasma in spring, implying that some RBP may not be complexed at this time of the year. In addition the fall in TBPA concentration may also have implications in thyroid hormone transport. The birds lack the high-affinity thyroid-hormone-binding globulin (Tata \& Shellabarger, 1959), having only the specific carrier prealbumin and albumin to mediate in the distribution of thyroid hormones.

Pure RBP and TBPA can be isolated relatively easily from the readily-available supplies

- Present address: Department of Biochemistry, Faculty of Science, University of Alexandria, Alexandria, Egypt. 
of domestic fowl plasma and antibodies to these proteins cross-react with those of Japanese quail (Heaf \& Glover, 1979; El-Sayed et al. 1980). These findings have led to the development of immunochemical and radioimmunoassay methods for use with tissues in vivo and in vitro. One of the early requirements of this series of investigations was to characterize the normal physiological changes in plasma RBP and TBPA in growing sexually-quiescent quail. We report here the changes in holoRBP, immunoreactive RBP (holoRBP plus apoRBP) and TBPA in relation to somatic growth and plasma total protein changes.

\section{MATERIALS AND METHODS}

Eggs were collected within a few hours of laying from fifteen female Japanese quail and immediately placed in an incubator. Collection and incubation were continued until twentyfive chicks were hatched. The chicks were raised in artificial lighting with $8 \mathrm{~h}$ light- $\mathrm{I} 6 \mathrm{~h}$ dark and had free access to food (Turkey Super Starter Crumbs, J. Bibby \& Co., Preston) and water throughout the experiment, which lasted 13 weeks. At approximately 4-5 weeks the birds were sexed on the basis of the appearance of the plumage and seven birds were rejected from the study either because they failed to thrive normally or in order to match the numbers of each sex.

The first blood sample from each bird was usually drawn within $48 \mathrm{~h}$ of hatching and thereafter every $3 \mathrm{~d}$ to approximately 3-4 weeks of age. For the remainder of the experiment a change from weekly to fortnightly sampling was made at approximately 9 weeks of age. As the birds were not hatched synchronously they were of different ages at each sample time. The values from analyses were classified into age groups having means as reported in 'Results'. Blood $(60 \mu l)$ was drawn from a superficial brachial wing vein, just proximal to where it passes over the ulna-radial-humeral joint. The vein was punctured with a syringe needle and blood was allowed to drain into a heparinized capillary tube which was then sealed in a fiame at one end and centrifuged to separate the plasma. The packed cell volume (PCV) was determined before the plasma was stored at $-20^{\circ}$. Body-weight was recorded at each sampling session.

HoloRBP was determined by u.v. fluorimetric scanning of the protein which was separated from other proteins in Io $\mu \mathrm{l}$ plasma subjected to electrophoresis on polyacrylamide gels (Glover et al. 1974). The determination of immunoreactive RBP, which is a measure of the sum of holoRBP and apoRBP, was carried out in triplicate by a typical double-antibody radioimmunoassay, as described previously (Heaf \& Glover, I979). TBPA was assayed in duplicate by radial immunodiffusion (Mancini et al. 1965), full details of which are reported elsewhere (El-Sayed et al. 1980 ). Plasma ( $5 \mu \mathrm{l})$ was used in each immunoassay. Total protein was determined by the method of Lowry et al. (195I), using bovine serum albumin as a standard.

\section{RESULTS}

At each sample time the age of the birds ranged over several days because they were not synchronously hatched. For the purposes of presentation of the results, individual values for the factors measured were classified into age-ranges of $3 \mathrm{~d}$ at the beginning of the experiment, increasing to $10 \mathrm{~d}$ at the end of the experiment. Body-weight values (Fig. I (a)) showed that somatic growth was complete at approximately $54 \mathrm{~d}$. There was no difference in mean $( \pm \mathrm{SD})$ body-weight $(\mathrm{g})$ between the sexes; $149 \pm 26$ for male birds and $145 \pm 43$ for female birds $(n 9)$.

Two haematological factors were monitored for comparison with the changes in the specific plasma proteins, in order to provide control over influences on their concentrations by haemoconcentration or dilution. PCV increased steadily (Fig. I (b)) from a mean value 

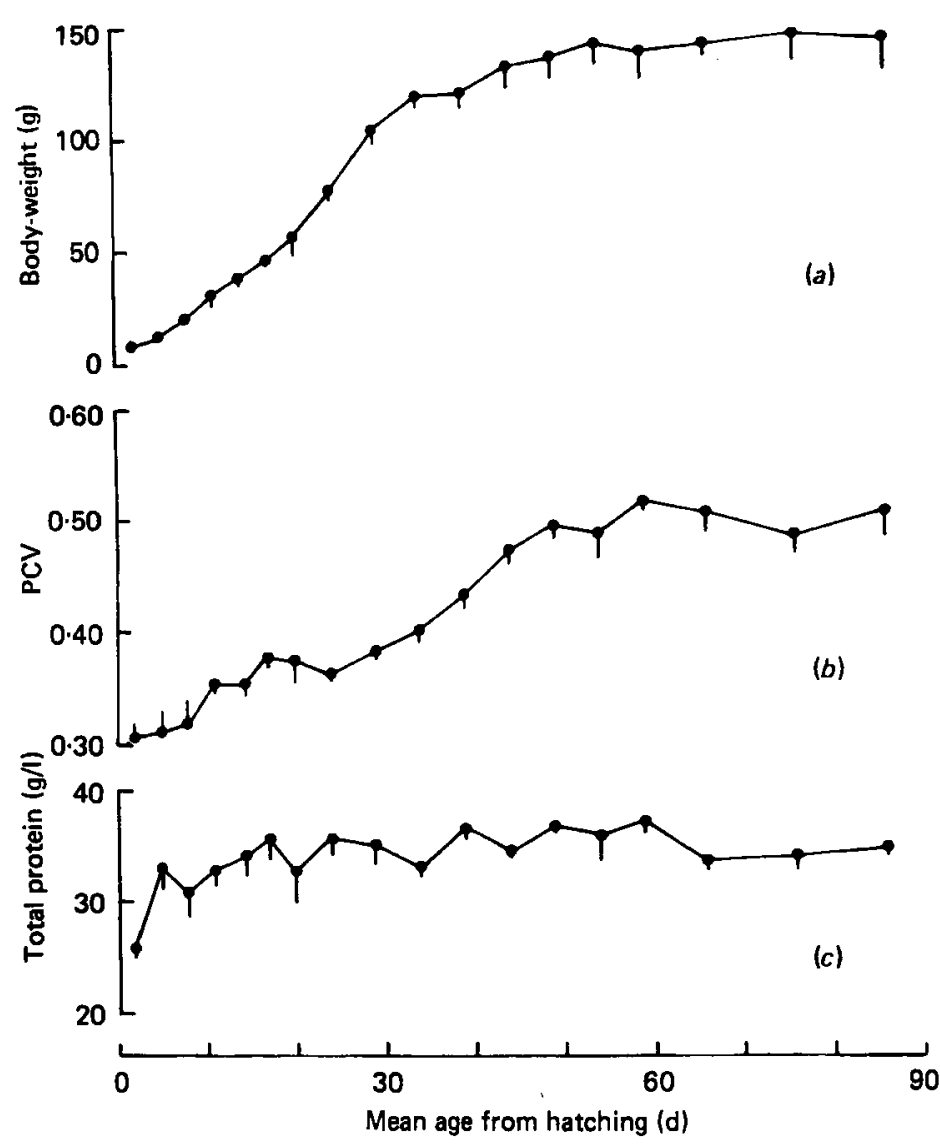

Fig. I. Changes in (a) body-weight (g), (b) blood packed cell volume (PCV) and (c) plasma total protein $(\mathrm{g} / \mathrm{l})$ following hatching in Japanese quail (Coturnix coturnix japonica). Each point shows the mean values with their standard errors represented by vertical bars for a minimum of five and a maximum of nine observations falling within each age-group.

of $0.3 \mathrm{I}$ in newly-hatched chicks to adult levels of approximately 0.50 at $50 \mathrm{~d}$ of age, remaining relatively constant thereafter. Mean ( \pm SD) PCV was $0.503 \pm 0.046$ in adult males and $0.485 \pm 0.045$ in adult females; these values were not significantly different. In contrast to PCV, total plasma protein (Fig. I (c)) rose relatively rapidly from $26 \mathrm{~g} / 1$ in newly-hatched birds, reaching to $33 \mathrm{~g} / \mathrm{l}$ at approximately $5 \mathrm{~d}$ of age; this value is close to mean ( $\pm \mathrm{SD}$ ) values for fully-grown quail: $36 \pm 2 \cdot 2 \mathrm{~g} / 1$ for male birds and $35 \pm 1.8 \mathrm{~g} / 1$ for female birds.

There were parallel changes in immunoreactive and holoRBP (Fig. $2(a)$ ) throughout the experiment. In four birds sampled within a few hours of hatching immunoreactive and holoRBP values were 60 and $45 \mu \mathrm{g} / \mathrm{ml}$ respectively. There was a steep rise in concentration of both immediately after hatching which terminated at plateau values approximately I $4 \mathrm{~d}$ later. After $50 \mathrm{~d}$ from hatching there was a second, though less pronounced, steady rise in both forms of RBP. No values for immunoreactive RBP were available after 10 weeks, the time selected for its simultaneous radioimmunoassay on samples up to that stage of the experiment. However, for holoRBP it was clear when comparing the mean value in birds aged $20-25 \mathrm{~d}(14 \mathrm{I} \mu \mathrm{g} / \mathrm{ml})$ with subsequent values $(\mathrm{I} 63 \mu \mathrm{g} / \mathrm{ml})$ that this second change in RBP concentration was statistically significant $(P<0.001$, paired $t$ test, $n 18)$. In the 

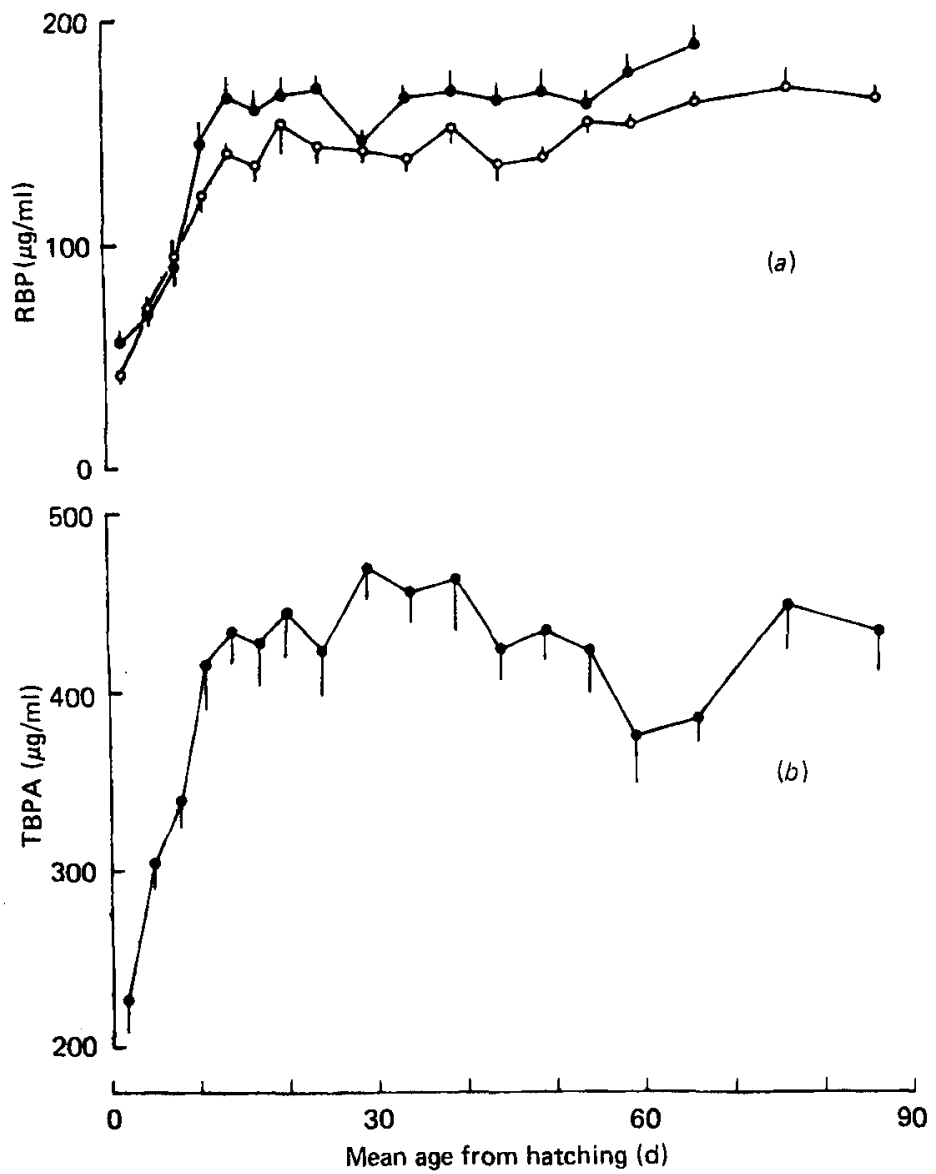

Fig. 2. Changes in (a) immunoreactive retinol-binding protein (RBP) (C-O) and holoRBP $(\mu \mathrm{g} / \mathrm{ml})(\mathrm{O}-\mathrm{O})$ and $(b)$ thyroxine-binding prealbumin (TBPA $\mu \mathrm{g} / \mathrm{ml})$ in the plasma following hatching in Japanese quail (Coturnix coturnix japonica). Each point shows the mean values with their standard errors represented by vertical bars for a minimum of five and a maximum of nine observations falling within each age-range.

fully-grown sexually-immature birds there was no difference in RBP concentration between the sexes.

Within a few hours of hatching the TBPA concentration (mean $\pm \mathrm{SD}$ ) was $200 \pm 40 \mu \mathrm{g} / \mathrm{ml}$ and rose rapidly to values typical of adults of this colony housed under short daily photoperiods $(430 \pm 50 \mu \mathrm{g} / \mathrm{ml})$. After $40 \mathrm{~d}$ of age there was a steady fall in TBPA concentration which was statistically significant $(P<0.05$, paired $t$ test, $n 18)$ when comparing mean values in the age-range $28-38 \mathrm{~d}$ with corresponding values at $56-58 \mathrm{~d}$. Towards the end of the experiment the mean concentration then returned to the previous value. There was no difference in TBPA concentrations between the sexes in the fully-grown birds in this experiment.

\section{DISCUSSION}

The growing quails showed a similar pattern of weight gain to that reported by Woodard et al. (1973), who found that the females were heavier than the males by approximately $30 \mathrm{~g}$. These authors did not use restricted lighting, whereas in the present study the failure to 
find this sex difference was probably because the birds were prevented from undergoing sexual development by exposure to short photoperiods. The increase in PCV with age has been shown previously for the quail (Atwal et al. 1964). The final adult PCV values were higher than those reported by Atwal et al. (1964) but similar to those of Nirmalan \& Robinson (I97I) who demonstrated a higher PCV in the male quail, in common with other avian species. The erythropoietic effect of testosterone and possible opposite effect of oestrogens, reviewed by Sturkie (1976), would account for this difference in sexually-mature quail (Nirmalan \& Robinson, 1971) and its abolition in quail maintained sexually immature as in the present study. Nirmalan \& Robinson (197I) also reported that female quail have a higher total plasma protein concentration than males, as in other bird species. The role of oestrogens in this respect (Griminger, 1976) would account for the lack of such a sex difference, because the development of the ovaries, and thus the secretion of oestrogens, was prevented by maintaining the birds under short photoperiods. The results for both total plasma protein and PCV showed that the growing quails were free from any gross disturbances of the main constituents of the blood, other than the normal developmental changes.

The parallel changes in both holoRBP and immunoreactive RBP in the growing birds are consistent with the fact that the radioimmunoassay measures holoRBP plus apoRBP, and the latter usually accounts for only 10-15\% of the total in sexually-immature birds. The absence in this experiment of any difference in RBP between the sexes, which has been found in man (Smith et al. 1970), sheep (Glover et al. 1976), rats (Kershaw, 1978) and Japanese quail (Glover \& Large, 1977), is almost certainly due to the birds remaining sexually immature. In man the expression of this sex difference is not attained until puberty (Vahlquist, 1975) and this was also observed in rats (Kershaw, 1978).

With regard to the development of birds, the chick egg was first shown to contain TBPA and RBP, having immunological and other properties identical with the corresponding plasma proteins (Heller, 1976). This was confirmed later for duck (Sreekrishna \& Cama, 1978) and Japanese quail (Heaf \& Glover, 1979; Heaf et al. 1980). Indeed, vitamin A, transported to the egg or embryo by the TBPA-RBP complex, is essential for embryogenesis in domestic fowl (Thompson et al. 1969), rat (Thompson et al. 1964) and quail (Thompson, 1970) although the contribution of the maternal proteins to the vitamin A transport system within the embryo is of greater importance in the rat (Takahashi $e t$ al. 1977) than in a close relative of the domestic fowl, the quail (Heaf et al. 1980). There are no values for plasma TBPA and RBP in developing quail embryos, but in domestic fowl, a rapid rise in both their concentrations relative to total protein by day 6 of development has been reported by Abe et al. (1976). They also found that the concentration of RBP in embryonic serum is higher relative to total protein than in the adult. For quail, we have calculated values of $2 \cdot 3 \mathrm{ng} \mathrm{RBP} / \mu \mathrm{g}$ total plasma protein shortly after hatching, rising to $4.3 \mathrm{ng} \mathrm{RBP} / \mu \mathrm{g}$ total plasma protein in the adult. The value for the young quail is more than fourfold higher than that in the domestic fowl embryo, but quail have the highest concentrations of plasma RBP of any species so far studied.

The delay of approximately $14 \mathrm{~d}$ in the development of adult levels of RBP and TBPA is not easily explained when considered alongside the evidence that the over-all biosynthetic capacity for plasma proteins is already sufficient to maintain concentrations of total proteins typical of the adult by approximately $5 \mathrm{~d}$ after hatching. It is possible in the instance of RBP that retinol, which is essential for the release of newly-synthesized RBP from the liver (Muto et al. I972; Muhilal \& Glover, 1974), may be limiting in the chick before it has hatched and gained access to fresh supplies in the diet. However, another explanation applicable to both TBPA and RBP is that their maximal rate of synthesis may be limited relative to other proteins since they have a greater content of essential amino acids, the supply of which may also be limited in the period before hatching. However, neither of these 
explanations would be applicable in human neonates, where similar developmental changes in TBPA and RBP (Vahlquist et al. 1975; Ingenbleek, 1977; Jacobsen et al. 1979) and other specific serum proteins (Gitlin \& Gitlin, 1975) have been shown to occur.

The smaller changes in both RBP and TBPA which occurred in the older birds are unlikely to be attributable to non-specific haematological disturbances or to the variations known to occur in both proteins during the natural breeding cycle (Heaf \& Glover, 1979; Glover et al. 1980; El-Sayed et al. 1980), because the stimulus for sexual development was eliminated by the use of short daily photoperiods. The slight increase in RBP after $55 \mathrm{~d}$ took place after the birds had ceased growing and may therefore represent a reduction in RBP utilization as the demand for retinol for the relatively rapid growth and differentiation of tissues was replaced by a lower requirement for maintenance of tissues only. The fluctuation in TBPA levels which took place at the same time remains unexplained. Values for the molar ratio, TBPA:holoRBP fall from 1.4 in newly-hatched birds to $\mathrm{I} \cdot 0$ in the adults, conditions which indicate that virtually all holoRBP is complexed in order to prevent losses through the kidney. However, the situation may be different for developmental changes in prealbumin in quails kept under long daily photoperiods, for which no information is available. Adult levels under these conditions are approximately half those reported here (El-Sayed et al. 1980), giving rise to values for TBPA:holoRBP of less than unity.

The main implications of the previously-mentioned findings for further experimental work on factors affecting the concentrations of RBP and PA in the plasma are that these factors reach a relatively steady concentration in quail older than $14 \mathrm{~d}$ rendering the birds suitable for experiments at this time, that fluctuations do occur requiring the provision of adequate controls in experiments and that the time of day when samples are taken for holoRBP measurements may be important particularly if the experimentally-induced changes being observed are small, i.e. of the order of $10-20 \%$.

This work was supported by a grant (No. AG 26/ I 17) from the Agricultural Research Council. Dr M. El-Sayed was in receipt of a Travelling Fellowship Award from the British Council.

\section{REFERENCES}

Abe, T., Muto, Y. \& Hosoya, N. (1976). Life Sci. 17, 1579.

Atwal, O. S., McFarland, L. Z. \& Wilson, W. O. (1964). Poultry Sci. 43, 1392.

El-Sayed, M., Heaf, D. J. \& Glover, J. (1980). Gen. Comp. Endocrinol. 4I.

Gitlin, D. \& Gitlin, J. D. (1975). In The Plasma Proteins. Structure Function and Genetic Control, 2nd ed. vol. 2, p. 264 [F. W. Putnam, editor]. New York: Academic Press.

Glover, J., Heaf, D. J. \& Large, S. (I980). Br. J. Nutr. 43, 357.

Glover, J., Jay, C., Kershaw, R. C. \& Reilly, P. E. B. (1976). Br. J. Nutr. 36, 137.

Glover, J. \& Large, S. (1977). Proc. Nutr. Soc. 36, 85A.

Glover, J., Moxley, L., Muhilal, H. \& Weston, S. (1974). Clinica chim. Acta 50, 37 I.

Griminger, P. (1976). In Avian Physiology, 3rd ed. p. 233 [P. D. Sturkie, editor]. New York: SpringerVerlag.

Heaf, D. J. \& Glover, J. (1979). J. Endocr. 83, 475.

Heaf, D. J., Pythian, B., El-Sayed, M. \& Glover, J. (1980). Int. J. Biochem. (In the Press.)

Heller, J. (1976). Devel. Biol. 5I, I.

Ingenbleek, Y. (1977). La malnutrition proteino-calorique chez l'enfant en bas age, repercussions sur la fonction thyroidienne et les proteines vectrices du serum. Thesis, University of Dakar.

Jacobsen, B. B., Peiterson, B., Andersen, H. J. \& Hummer, L. (1979). Acta Paediat. scand. 68, 49.

Kanai, M., Raz, A. \& Goodman, D. S. (1968). J. clin. Invest. 47, 2025.

Kershaw, R. C. (1978). Factors controlling plasma retinol-binding protein. PhD Thesis, University of Liverpool.

Lowry, O. H., Rosebrough, N. J., Farr, A. L. \& Randall, R. J. (I95I). J. biol. Chem. 193, 265.

Mancini, G., Carbonara, A. O. \& Heremans, J. F. (1965). Immunochemistry 2, 235.

Muhilal, H. \& Glover, J. (1974). Br. J. Nutr. 32, 549.

Muto, Y., Smith, J. E., Milch, P. O. \& Goodman, D. S. (1972). J. biol. Chem. 247, 2542. 
Nirmalan, G. P. \& Robinson, G. A. (197I). Br. Poult. Sci. 12, 475.

Smith, F. R., Raz, A. \& Goodman, D. S. (1970). J. clin. Invest. 49, 1754.

Sreekrishna, K. \& Cama, H. R. (1978). Indian J. Biochem. Biophys. 15, 255.

Sturkie, P. D. (1976). In Avian Physiology, 3rd ed., p. 54 [P. D. Sturkie, editor]. New York: Springer-Verlag. Takahashi, Y. I., Smith, J. E. \& Goodman, D. S. (1977). Am. J. Physiol. 233, 263.

Tata, J. R. \& Shellabarger, C. J. (1959). Biochem. J. 72, 608.

Thompson, J. N. (1970). In Fat Soluble Vitamins, p. 267 [J. F. De Luca and J. W. Suttie, editors]. Madison: University of Wisconsin Press.

Thompson, J. N., Howell, J. McC. \& Pitt, G. A. J. (1964). Proc. R. Soc. B I59, 510.

Thompson, J. N., Howell, J. McC., Pitt, G. A. J. \& McLaughlin, C. (1969). Br. J. Nutr. $23,471$.

Vahlquist, A., Rask, L., Peterson, P. A. \& Berg, T. (1975). Scand. J. clin. Lab. Invest. $35,569$.

Woodard, A. E., Abplanalp, H., Wilson, W. O. \& Vohra, P. (1973). In Japanese Quail Husbandry in the Laboratory, p. 22. Department of Avian Sciences, University of California. 